\title{
PROBLEMATIKA INTERNALISASI PENDIDIKAN KARAKTER DI INDONESIA
}

\section{AYI DINI PURWANDI}

\begin{abstract}
The purpose of this study is to analyze the problems of internalizing character education in Indonesia using several methods, including meta-analysis. the way to formulate the problem of this research begins with conducting observations, then tracing the results of other relevant research to be analyzed. The research data consisted of six journal articles and four theses that had been tried. The process of data analysis is done by descriptive qualitative method. The results of the analysis show that there is a problem in internalizing character education in Indonesia because the current problem of internalizing character education is (a) students' lack of interest in practicing the nation's character and culture (b) The internalization system of character values in schools is not continued by the environment outside the school (c) Crisis exemplary (d) Foreign culture that is not in accordance with the culture and character of the Indonesian nation is entered into a large scale (e) Learning programs that are less relevant to the times. The expected solution to the internalization of character education is (a) conceptual approach (b) systematic / habituation approach (c) modeling / exemplary approach. The educational model for character development in adolescents is integrated in school regulations, learning and extracurricular activities, namely scout extracurricular activities. Based on the results of the analysis it can be concluded that an effective character education model is built from a school climate that is conducive to the development of positive character both through learning models at school.
\end{abstract}

Keywords: Problems of internalization, character education

\section{Pendahuluan}

Kepribadian seseorang ditunjukkan dalam perilaku kehidupannya seharihari, hal itulah yang di sebut karakter. Kemampuan kognitif dan sifat-sifat lainnya telah ditunjukan oleh manusia sejak lahir, hal itulah yang disebut dengan karakter bawaan, karakter bawaan bisa dikembangkan jika di lingkungannya mendapat sentuhan pengalaman belajar. Menurut Endang Suryaningsih (2011:2) Lingkungan belajar pertama anak adalah keluarga. Karakter lingkungan akan menjadi fondasi yang kuat untuk membentuk karakter anak ketika beranjak dewasa. Menurutnya hampir 50\% kecerdasan dan karakter anak terbentuk di lingkungan keluarga sekitar usia 4 Tahun. Bahkan 30\% selanjutnya terbentuk di usia delapan tahun, dan 20\% sisanya pada di dasawarsa kedua (Suyanto, 2010). Kecerdasan manusia dan mental seiringan sampai usia remaja. Perilaku dan kepribadian akan stabil ketika usia dewasa, oleh karenanya jika ingin membentuk kecerdasan, mental dan karakter, paling tepat adalah waktu pada saat usia anak-anak sampai dengan remaja. 
Beberapa hasil penelitian menunjukkan adanya problem internalisasi pendidikan karakter di Indonesia, juga adanya beberapa hasil penelitian dan kajian yang menemukan solusi atas problematika internalisasi pendidikan karakter di Indonesia. Bahkan pemerintah telah lama memperhatikan pendidikan karakter. Undang-undang nomor 20 tahun 2003 tentang Sistem Pendidikan Nasional pada pasal 1 antara lain disebutkan bahwa untuk mengembangkan potensi diri dengan kekuatan spiritual, akhlak serta keterampilan maka perlu model pendidikan yang secara sadar dan terencana supaya hasilnya dapat berguna bagi bangsa dan negara.

Selain di dalam Undang-undang, sebagai upaya penerapan internalisasi pendidikan karakter di Indonesia ialah karakter positif juga banyak ditulis dalam visi dan misi lembaga pendidikan. Pada umumnya, lembaga pendidikan menyusun visi yang tidak hanya bermuatan untuk menjadikan lulusannya cerdas tetapi juga berakhlak mulia, hal itu sebagai upaya untuk menangkal siswa siswi dari pergaulan bebas pada masa ini. karenanya internalisasi pendidikan karakter Agama Islam dipandang akan mampu membuat sebuah solusi dari problematika pendidikan karakter di Indonesia saat ini.

Penelitian yang dilakukan dalam menyusun artikel ini ialah akan berfokus terhadap problem yang menjadi penghambat dalam penerapan internalisasi pendidikan karakter di sekolah serta solusi yang timbul dari latar belakang sehingga menjadi jawaban atas segala problematika yang terjadi khususnya di lembaga pendidikan. Penelitian ini akan menjadikan sebuah khazanah keilmuan baru dalam dunia pendidikan dimana intrakurikuler dan ekstrakulikuler menjadi sebuah perbandingan dalam proses internalisasi pendidikan karakter di sekolah. Banyak teori para ahli yang akan dijadikan reperensi seperti menurut Rahman (2015:2) lembaga pendidikan harus menciptakan susana yang religius sehingga menciptakan suasana yang kondusif dalam pembelajaran dan akan menghasilkan sebuah karakter pada siswa.

Problematika ialah suatu hambatan internalisasi dalam suatu proses sehingga tidak menjadikan sebuah hasil yang maksimal, problematika dalam proses internalisasi pendidikan karakter menjadi sebuah sandungan yang cukup serius harus dipecahkan oleh para ahli peneliti karena dalam proses kegiatan pembelajaran akan mengurangi terhadap kualitas karakter siswa yang diharapakan. Sementara internalisasi berasal dari bahasa inggris internalization ialah suatu proses dalam mentransformasi nilai atau sikap idealis yang sebelumnya dianggap kurang efektif berada, supaya terhubung dalam pemikiran seseorang, keterampilannya dan sikap sehari-hari seseorang. Internalisasi dimaksudkan dan diterjemahkan dengan pengumpulan sikap atau pengumpulan nilai tertentu agar terbentuk menjadi kepribadian yang mantap. Dengan demikian internalisasi dapat pula diartikan sebagai suatu metode, teknik dan prosedur dalam manajerial pengetahuan yang digunakan oleh para guru untuk memberikan kesempatan kepada siswa siswi binaannya, instansi, organisasi, perusahaan agar berbagi pengetahuan yang mereka miliki kepada anggotanya atau kepada orang lain. (Rahman, 2015: 5). 


\section{Metode}

Berdasarkan rumusan masalah yang menjadi fokus topik kajian ini akan mendeskripsikan secara detail dan mendalam tentang faktor yang menjadi problematika internalisasi pendidikan karakter di Indonesia. Maka, penelitian ini akan menggunakan pendekatan deskriptif-kualitatif. Penelitian dilakukan di Sekolah Menengah Kejuruan (SMK) Plus Al-Hasanah Budiman Gunung Tanjung Kabupaten Tasikmalaya pada September-Desember 2019. Sumber data dalam penelitian ini adalah informan, aktivitas, dan dokumen, sehingga pengumpulan data menggunakan wawancara, observasi, dan kajian dokumen. Analisis yang dilakukan adalah analisis interaktif yang terdiri atas beberapa tahap, yakni reduksi data, penyajian data, dan penyimpulan yang dilakukan secara terus menerus. Hasil analisis lapangan di bandingkan juga dengan beberapa hasil penelitian sebelumnya yang sudah dilakukan oleh para peneliti yang sudah di muat pada jurnal nasional maupun tesis di perguruan tinggi lainnya. Hasil perbandingan tersebut kemudian di jadikan Verifikasi dan Penarikan kesimpulan, dimaksudkan sebagai upaya memberikan makna terhadap data yang telah dikumpulkan dan disajikan. Dalam memaknai peneliti memberi tafsiran dengan mengkaitkan kategori (misal, teori) yang mendukung. Upaya mencari makna dari data yang telah disajikan ini disebut verifikasi. Varifikasi dapat dilakukan dengan mencari data untuk mencapai persetujuan bersama untuk lebih menjamin validitasnya. Kesimpulan disusun dalam bentuk pernyataan singkat, namun mudah dipahami, tentunya dengan mengacu kepada fokus masalah yang diteliti.

\section{Problematika Internalisasi Pendidikan Karakter}

Problematika internalisasi pendidikan karakter menjadi suatu konsep atau pekerjaan yang menghambat dalam pembelajaran, problematika berasal dari bahasa Inggris "problematic" yang berarti masalah atau persoalan (Jhon $M$ Echoles, 2000:440). Problematika berasal dari kata problem yang dapat diartikan permasalahan atau masalah. Masalah yang kita hadapi adalah suatu persoalan atau kendala yang memerlukan pemecahan masalah dengan kata lain masalah merupakan kesenjangan antara kenyataan dengan suatu yang diharapkan dengan baik, agar tercapai hasil yang maksimal. Terdapat juga di dalam Kamus Besar Bahasa Indonesia kata problematika berarti masih menimbulkan masalah; hal-hal yang masih menimbulkan suatu masalah yang masih belum dapat dipecahkan (Depdiknas, 2005:896) Jadi, yang dimaksud dengan problematika adalah kendala atau permasalahan yang masih belum dapat dipecahkan sehingga untuk mencapai suatu tujuan menjadi terhambat dan tidak maksimal.

Internalisasi merupakan merupakan teknik dalam pendidikan nilai, yang menurut Chabib Thoha (2005:87-93) sasarannya adalah sampai pada pemilikan nilai yang menyatu dalam kepribadian peserta didik. Internalisasi nilai adalah proses menjadikan nilai sebagai bagian dari diri seseorang. Lebih lanjut dijelaskan bahwa proses tersebut tercipta dari pendidikan nilai dalam pengertian yang sesungguhnya, yaitu terciptanya suasana, lingkungan dan interaksi belajar mengajar yang memungkinkan terjadinya proses sosialisasi dan internalisasi nilainilai. Internalisasi akan menjadi dominan melalui komunikasi yang intensif dalam 
bentuk sosialisasi dan kegiatan belajar mengajar. Hal terpenting dalam menjalankan proses internalisasi adalah nilai-nilai yang harus ditanamkan. Setelah manusia mengerti tentang nilai-nilai, maka akan dibentuk menjadi sebuah kepribadian.

Teori beberapa ahli yang sudah dibahas sebelumnya, dapat disimpulkan bahwa internalisasi sebagai proses penanaman nilai kedalam jiwa seseorang sehingga nilai tersebut akan tercermin dalam sikap dan prilaku yang dalam kehidupan sehari-hari (menyatu dengan pribadi). Nilai-nilai yang diinternalisasikan merupakan nilai yang sesuai dengan norma dan aturan-aturan yang berlaku di masyarakat.

Ki Hajar Dewantara, Tokoh pendidikan Indonesia mempelopori Platform pendidikan karakter bangsa Indonesia dengan 3 kalimat yaitu: Ing ngarsa sung tuladha, Ing madya mbangun karsa, Tut wuri handayani. Ing ngarsa sung tuladha (Di depan memberikan teladan). Artinya seorang guru memberikan harus contoh, teladan dan panutan kepada peserta didiknya. Karena guru adalah cerminan bagi siswanya maka guru senantiasa memberikan panutan-panutan yang baik sehingga dapat di jadikan teladan bagi para peserta didiknya. Ing madya mbangun karsa (Ditengah membangun kehendak). Guru memberikan rasa optimisme di tengah-tengah pergaulan bersama peserta didiknya guru menyatukan tujuan dan cita-cita peserta didiknya agar hidupnya terarah. Seorang guru harus berkonsolidasi dengan memberikan bimbingan yang continue dan mengambil keputusan dengan musyawarah mufakat yang mengutamakan kepentingan peserta didik di masa depannya. Tut wuri handayani (Di belakang memberikan dorongan). Guru memiliki makna "digugu dan ditiru" (diikuti dan dicontoh) dengan demikian guru harus memberikan pendidikan karakter kepada peserta didiknya, peserta didik akan melihat profil dan penampilan guru, maka seharusnya guru harus mendorong siswanya memiliki sifat-sifat yang dapat membawa peserta didiknya ke arah pembentukan karakter. dalam konteks ini guru memberikan motivasi kepada peserta didiknya agar berkembang secara emosional dan karakternya.

Karakter disebutkan dalam kamus besar bahasa Indonesia bahwa karakter adalah sifat kejiwaan, budi pekerti yang membedakan dirinya dengan orang lain. Sedangkan pendidikan karakter merupakan suatu sistem penanaman nilai-nilai karakter kepada warga sekolah yang meliputi komponen pengetahuan, kesadaran atau kemauan. Pendidikan karakter pada hakekatnya ingin membentuk individu menjadi seorang pribadi bermoral yang dapat menghayati kebebasan dan tanggung jawabnya, dalam relasinya dengan orang lain dan dunianya dalam komunitas pendidikan. Dengan demikian pendidikan karakter senantiasa mengarahkan diri pada pembentukan individu bermoral, cakap mengambil keputusan yang tampil dalam perilakunya, sekaligus mampu berperan aktif dalam membangun kehidupan bersama (Fihris, 2010:24-28). Lebih dari itu, pendidikan karakter merupakan usaha sadar melakukan kebiasaan-kebiasaan yang baik sehingga peserta didik mampu bersikap dan bertindak berasaskan nilai-nilai yang telah menjadi kepribadiannya. Nilai-nilai tersebut harus dikembangkan pada setiap peserta didik hingga menjadi karakter siswa dan berkembang menjadi budaya sekolah.

Pendidikan karakter di Indonesia di masa sekarang sangat relevan untuk mengatasi krisis moral yang sedang melanda di negara kita. Krisis tersebut 
antara lain berupa meningkatnya beberapa kasus seperti maraknya angka kekerasan anak-anak dan remaja, pergaulan bebas, kebiasaan menyontek, pencurian remaja, kejahatan terhadap teman, perusakan milik orang lain sudah menjadi masalah sosial yang hingga saat ini belum dapat di atasi secara tuntas. oleh karena itu betapa pentingnya pendidikan karakter saat ini. Karena karakter adalah tabiat atau kebiasaan. Ahli psikologi menyebutkan karakter merupakan sistem kebiasaan dan keyakinan yang mengarahkan tindakan seorang individu. Karena itu, jika karakter seseorang itu dapat diketahui, maka dapat diketahui pula bagaimana individu tersebut akan bersikap untuk kondisi-kondisi tertentu. (Singh \& Arwan, 2000:1).

Melihat realita dilapangan tidak berlebihan jika dikatakan bahwa pendidikan karakter masih menyimpan beberapa problematika penanaman nilai. Hasil observasi lapangan ke SMK Al Hasanah budima Kecamatan gunung tanjung Kabupaten tasikmalaya dengan melakukan wawancara ke beberapa guru bidang PAI, PKN dan Pembina Pramuka yang dalam keseharian tugasnya bersentuhan dengan internalisasi pendidikan karakter, tentunya disini penliti menggali problematika yang terjadi untuk merumuskan solusi dari problematika tersebut, di antaranya (1) Siswa kurang tertarik memahami dan mengamalkan nilai karakter dan budaya bangsa. kendala yang muncul menurut Martin (Wawancara 28 September 2019) adalah bahwa berkembangnya globalisasi, terutama dalam hal teknologi informasi telah menyebabkan masyarakat yang memiliki logika materialistis dan bersifat pragmatis. Hal ini menjadi kendala yang sangat menghambat proses pendidikan karakter. Masalah ini terjadi karena guru maupun orang tua kadang kala tidak dapat membatasi arus informasi yang begitu deras untuk siswa. Siswa saat ini memiliki akses yang luas dalam mengakses informasi yang beraneka ragam. Kendala dari aspek guru tampak dari adanya kesenjangan pemahaman guru tentang karakter dan pendidikan karakter itu sendiri. Banyak siswa yang kurang memperhatikan aspek karakter mulia dalam sehari-harinya, ini terbentuk seiring dengan penanaman opini dan informasi yang selalu mengedapankan ideologi matrealistis dan hedonis. Dalam dunia pendidikan, ranah kognitif cukup dominan dalam memberikan apresiasi, sehingga banyak siswa hanya mengejar hasil belajar ke ranah prestasi akademik atau hanya mengejar koognitif semata. Hal ini terbukti sampai saat ini masih melihat hasil ujian berbasis pengetahuan menjadi dasar untuk menentukan prestasi siswa, menjadi syarat masuk ke jenjang pendidikan selanjutnya bahkan untuk suatu syarat melamar pekerjaan sehingga siswa banyak yang rela melakukan kecurangan ataupun manipulasi demi mencapai target tertentu. (2) Sistem internalisai nilai pendidikan karakter disekolah tidak diteruskan oleh lingkungan diluar sekolah. Menurut Dian Herdian (Wawancara 28 September 2019) saat ini banyak sekolah yang sudah mencoba menerapkan sistem pendidikan karakter dengan baik dengan berbagai progamnya, namun masih mudah untuk diputar balikan oleh lingkungan masyarakat maupun keluarga dimana siswa berinteraksi sosial. Internalisasi nilai karakter belum bisa terintegrasi dengan baik antara lingkungan sekolah, keluarga maupun masyarakat.oleh karenanya parenting / komunikasi singkronisasi antara sekolah dan lingkungan keluarga harus ada penghubung baik secara laporan tertulis atau melalui media komunikasi. Hal ini bisa dilakukan oleh walikelas terhadap orang tua siswa binaannya ataupun melalui bagian konseling. Di SMK Plus Al Hasanah Baru terjalin melalui walikelas saja. Sementara bina konseling baru sebatas penanganan siswa 
bermasalah saja. (3) Krisis keteladanan. Ai Enday (Wawancara, 28 September 2019) menyatakan bahwa kendala dalam internalisasi nilai karakter bersifat abstrak, sehingga kita sulit untuk menerapkannya pada siswa. Oleh karena itu ini menjadi kendala ketika guru tidak dapat memberikan contoh perilaku yang nyata dan keteladanan pada siswa. Ini karena pendidikan karakter dalah proses yang panjang, sehingga internalisasi tidak bisa langsung dirasakan hasilnya. Dari beberapa penilaian masih banyak guru yang hanya berfungsi sebagai pengajar bukan pendidik. Mereka hanya fokus mengajar tanpa memperhatikan posisi dirinya sebagai pendidika, pengajar dan pembina. Keadaan yang seperti ini belum bisa menjawab kebutuhan siswa tentang kehadiran sesosok figur pendidik untuk diteladani. Hal ini diperparah dengan perilaku oknum sebagian public figure, pejabat politik, dan artis lainnya yang menyimpang dan terus menerus di expose di media masa sehingga hal ini justru yang mudah ditirukan oleh siswa. (4) Budaya asing yang tidak sesuai dengan karakter dan budaya bangsa Indonesia masuk secara besar-besaran. Perkembangan teknologi dan informasi memang tidak bisa dihindari lagi, beberapa negara kewalahan dengan cara mempertahankan karakter dan budayanya menghadapi arus tersebut. Budaya bangsa lain sangat mudah masuk dan mempengaruhi perilaku siswa, padahal tidak semua budaya bangsa asing sesuai dengan karakter dan budaya bangsa Indonesia, sehingga lambat laun akan menggeser nilai karakter dan budaya bangsa sendiri menurut Ari Nugroho (Wawancara, 28 September 2019) di SMK Plus Al Hasanah sudah ada upaya-upaya untuk menngkal hal tersebut dengan memperbanyak pelajara pendidikan Islam merupakan satu upaya yang integrasi dengan kurikulum sekolah. Selalin melalui kegiatan belajar mengajar upaya tersebut juga sering dilakukan dengan membuat tatatertib sekolah dan pembinaan ketika upacara hari senin atau kegiatan lainnya. (5) Program pembelajaran yang kurang relevan dengan perkembangan zaman Hasil wawancara dengan bapak Ari Nugroho Guru Pendidikan agama Islam (wawancara pada 25 November 2019) menjelaskan bahwa internalisasi pendidikan karakter terkendala dengan sistem perangkat pembelajaran, Hal ini karena menurutnya guru selama ini masih terbiasa dengan pola lama. Perangkat pembelajaran dianggap sebagai bagian administrative yang seolah-olah tidak menjadi bagian pembelajaran di kelas. Ia menambahkan bahwa pengembangan perangkat berperspektif EEK (Eksplorasi, Elaborasi, Konfirmasi) masih terkendala karena belum adanya format yang baku dan pelatihan penyusunannya bagi guru. Kendala kedua ditinjau dari pelaksanaan pembelajaran, meliputi kondisi siswa, guru, materi, metode, media, evaluasi, dan pendukung. Ditinjau dari segi siswa, dari segi materi, seharusnya guru menjadikan pendidikan Agama Islam sebagai best practices tentang mana yang dapat ditiru dan mana yang tidak. Namun ketika suatu peristiwa banyak mengandung masalah negatif dan kontroversial, hal ini masih menjadi kendala. Misalnya adalah materi tentang jihad. "terkadang siswa memiliki penilaian jihad lebih ke jihad fisik atau perang sehingga di khawatirkan radikalisme, padahal jihad bisa juga dengan menahan hawa nafsu ataupun berjuang demi agama Alloh adalah jihad juga. Di SMK Plus Al Hasanah Upaya upaya peningkatan kapasitas mutu pendidik terus dilakukan supaya ada kesinambungan dengan perkembangan zamannya melalui peningkatan mutu musyawarah guru mata pelajaran (MGMP) atau seminar-seminar yang dilakukan berbagai instansi guna meningkatkan kapasitas pendidik dalam pembelajaran. 
Sementara untuk solusi problematika internalisasi pendidikan karakter di indonesia Banyak faktor yang mempengaruhi Proses pembentukan karakter seseorang, sekolah sebagai media dan pemeran utama yang menjadi ujung tombak dari progam pendidikan karakter tentunya akan mempunyai peranan yang cukup besar untuk menanamkan nilai-nilai karakter pada siswa. Melihat dari proses internalisasi nilai pada uraian sebelumnya, maka untuk meminimalisir problematika internalisasi pendidikan karakter menurut M Fahmi (2017:5) perlu pendekatan penanaman nilai dilakukan dengan beberapa pendekatan yang salih berkaitan, yaitu (1) Pendekatan konseptual Yaitu pendekatan yang dilakukan kepada siswa dengan memberikan pemahaman arti konsep pendidikan supaya terarah dan selaras antara berfikir dan bertindak. Konseptual pendidikan ini sangat penting karena akan menanamkan pola pikir, motivasi dan keyakinan untuk menjadikan perbuatan sebagai realisasi dari konsep. Pendekatan ini juga berfungsi memberikan penafsiran atas model pendekatan yang lainnya sehingga siswa tidak salah persepsi dan salah memaknai perlakuan terhadap pendekatan ini serta dapat penanaman nilai - nilai karakter lainnya. (2) Pendekatan sistematis/pembiasaan Pendekatan sistematis bisa dilakukan oleh lembaga dengan konsep suatu rencana yang teratur, berkesinambungan dan konsisten sehingga akan muncul menjadi budaya sekolah, model pendekatan ini sangat efektif karena semua wara sekolah akan bergerak dengan sistem pembiasaan yang secara otomatis akan menginternalisasi nilai-nilai karakter dalam pembiasaan yang sudah di rencanakan. (3) Pendekatan modeling/keteladanan Pendekatan modeling/keteladanan merupakan suatu pendekatan dalam upaya menanamkan nilai-nilai karakter menampilkan tingkah laku sehari-hari sebagai cerminan siswa terhadap model karakter dan pembiasaan yang ada pada pendidik. Pendekatan ini sudah terbukti bahkan fakta sejarah mengingatkan pendidikan karakter dengan memberikan contoh atau keteladanan sangat efektif dan cukup berhasil, bahkan bisa mengubah suatu budaya bangsa. seperti yang telah dicontohkan dilakukan oleh nabi kita semua yaitu Nabi Muhammad SAW dalam memperbaiki budaya bangsa Arab. Dalam pendekatan keteladanan guru / pendidik diharuskan untuk lebih dulu mampu bertindak dan berperilaku sesuai dengan nilainilai karakter yang akan ditanamkan pada siswa. Sementara itu upaya proses internalisasi yang akan dikaitkan dengan model pembinaan peserta didik atau anak asuh ada tiga tahap yang akan mewakili proses atau tahap terjadinya internalisasi (Muhaimin, 1996 : 153), yaitu (1) tahap transformasi nilai. tahap ini merupakan suatu proses yang dilakukan oleh guru dalam menginformasikan nilai-nilai karakter yang baik dan kurang baik. pada tahap ini hanya terjadi komunikasi verbal antara guru/pendidik dan peserta didik atau anak asuh. (2) tahap transaksi nilai. tahapan ini merupakan suatu tahap pendidikan nilai dengan jalan melakukan komunikasi dua arah, atau interaksi antara peserta didik dengan pendidik yang bersifat interaksi timbal-balik. (3) tahap transinternalisasi. Tahap ini jauh lebih mendalam dari tahap transaksi. Pada tahap ini bukan hanya dilakukan dengan komunikasi verbal tapi juga sikap mental dan kepribadian. Jadi pada tahap ini komunikasi kepribadian yang berperan secara aktif (Muhaimin, $1996: 153$ ).

Nilai-nilai yang diinternalisasikan adalah yang berkaitan dengan olah pikir (agar anak cerdas), olah hati (religius, jujur, bertanggung jawab), olahraga (bersih dan sehat), olah rasa dan karsa, peduli dan kreatif yang muaranya menuju nilai-nilai luhur dan perilaku berkarakter. Proses penanaman internalisasi pendidikan karakter 
di lingkungan sekolah tidak dapat dilakukan secara instan, namun secara bertahap dan dilakukan secara terus-menerus atau secara berkelanjutan. Upaya menginternalisasi pendidikan karakter di sekolah-sekolah dapat dilakukan berbagai cara, tergantung dari lembaga sekolah tersebut dalam mengemasnya. Selain internalisasi karakter seperti yang dicontohkan di atas dalam bentuk peraturan umumnya, proses internalisasi dapat dilakukan dengan.

Pendidikan karakter di sekolah memiliki tujuan sebagai berikut: (a) Menguatkan dan mengembangkan nilai-nilai kehidupan yang dianggap penting dan perlu sehingga menjadi kepribadian/kepemilikan peserta didik yang khas sebagaimana nilai-nilai yang dikembangkan. (b) Mengoreksi perilaku peserta didik yang disesuaikan dengan nilai-nilai yang dikembangkan oleh sekolah. (c) Membangun koneksi yang harmoni dengan keluarga dan masyarakat dalam memerankan tanggung jawab pendidikan karakter secara bersama.

\section{Kesimpulan}

Kesimpulan dari pembahasan problematika internalisasi pendidikan karakter di indonesia serta solusi yang diharapkan dalam mengatasi problem tersebut antara lain; (1) problematika internalisasi pendidikan karakter saat ini ialah (a) siswa kurang tertarik memahami dan mengamalkan nilai karakter dan budaya bangsa (b) sistem internalisai nilai karakter disekolah tidak diteruskan oleh lingkungan diluar sekolah (c) krisis keteladanan (d) budaya asing yang tidak sesuai dengan karakter dan budaya bangsa indonesia masuk secara besar-besaran (e) program pembelajaran yang kurang relevan dengan perkembangan zaman. (2) solusi problematika internalisasi pendidikan karakter yang diharapkan saat ini ialah (a) pendekatan konseptual (b) pendekatan sistematis/pembiasaan (c)pendekatan modeling/ keteladanan. kemudian dalam proses internalisasi yang dikaitkan dengan pembinaan peserta didik atau anak asuh ada tiga tahap yang mewakili proses atau tahap terjadinya internalisasi.

\section{DAFTAR PUSTAKA}

Ahmad Ramdhani (2013) Strategi Guru Dalam Internalisasi Pendidikan Karakter Pada Pembelajaran. Semarang: UNES

Chatib Toba (1996) Kapita Selekta Pendidikan Islam, Yogyakarta: Pustaka Pelajar.

Departemen Agama RI, (2010) Pedoman Pendidikan Agama Islam sekolah Umum dan Luar Biasa. Jakarta. Depag RI

Kartono Kartini (1996) Pengantar Metodologi Riset Social. Bandung: Mandar Maju,

Kharisul Wathoni (2016) Internalisasi pendidikan karakter di perguruan tinggi Ponorogo: STAIN Ponorogo

Larry P. Nuccci \& Dercia Narvaez (2008), Handbook of moral and character education, routledge. New York: Routledge 
Muhammad Mahmud (2017) Internalisasi Nilai-Nilai Karakter dalam meningkatkan kompetensi gur., Malang: UIN MMI Malang.

Qurrota'ayun (2017) Internalisasi Nilai-Nilai karakter peserta didik dalam ekstrakulikuler hadroh. Purwokerto: IAIN Purwokerto.

Rahman (2015) Nilai-Nilai Pendidikan Karakter dalam dasa darma pramuka. Ciamis : IAID

Tsabit Azinar Ahmad, dkk. (2008) "Pendekatan Kritis dalam Pembelajaran Sejarah Untuk pendidikan karakter di Sekolah Menengah Atas untuk Mewujudkan Kesadaran Sejarah Peserta Didik". Karya Tulis Ilmiah. Dipresentasikan dalam KKTM Bidang Pendidikan Tingkat Nasional pada 17 Juli 2008.

Wahyu (2011) Masalah dan Usaha Membangun Karakter bangsa, diunduh di http://journal.unes.ac.id/nju/indek/php/komunitas. 
